\title{
Accelerated telomere shortening and senescence in human pancreatic islet cells stimulated to divide in vitro
}

\author{
T L Halvorsen, G M Beattie ${ }^{1}$, A D Lopez ${ }^{1}$, A Hayek ${ }^{1}$ and \\ F Levine
}

Center for Molecular Genetics, University of California San Diego School of Medicine, San Diego, California 92093-0634, USA

${ }^{1}$ Whittier Institute for Diabetes, University of California San Diego School of Medicine, San Diego, California 92093-0983, USA

(Requests for offprints should be addressed to F Levine, University of California San Diego, Center for Molecular Genetics, Room 122, La Jolla, California 92093-0634, USA; Email: flevine@ucsd.edu)

(T L Halvorsen and G M Beattie contributed equally to this paper)

\begin{abstract}
Widespread application of $\beta$-cell replacement strategies for diabetes is dependent upon the availability of an unlimited supply of cells exhibiting appropriate glucose-responsive insulin secretion. Therefore, a great deal of effort has been focused on understanding the factors that control $\beta$-cell growth. Previously, we found that human $\beta$-cell-enriched islet cultures can be stimulated to proliferate, but expansion was limited by growth arrest after 10-15 cell divisions. Here, we have investigated the mechanism behind the growth arrest. Our studies, including analyses of the
\end{abstract}

expression of senescence-associated $\beta$-galactosidase, $\mathrm{p} 16^{\text {INK4a }}$ levels, and telomere lengths, indicate that cellular senescence is responsible for limiting the number of cell divisions that human $\beta$-cells can undergo. The senescent phenotype was not prevented by retroviral transduction of the hTERT gene, although telomerase activity was induced. These results have implications for the use of primary human islet cells in cell transplantation therapies for diabetes.

Journal of Endocrinology (2000) 166, 103-109

\section{Introduction}

Transplantation of glucose-responsive insulin-secreting cells holds great promise as a definitive treatment for diabetes. Because of the complex biology of the cellular machinery involved in glucose-responsive insulin secretion, pancreatic $\beta$-cells and $\beta$-cell precursors are the best candidates for a cell-based diabetes therapy. Unfortunately, a major limiting factor in realizing their potential is the scarcity of such cells. Pancreas transplants cure diabetes, but this option is limited by organ availability (only a few thousand per year) and the need for major surgery and chronic immunosuppression. Islet transplantation is attractive because it involves only minor surgery and may require less immunosuppression if the islet cells are shielded from the immune response by encapsulation or some other means. However, islet transplants have been much less successful than whole-organ transplants. The reason for this seems to be that many cells die in the immediate post-transplant period (Davalli et al. 1996), leading to a requirement for large numbers of cells to achieve long-term insulin independence (Keymeulen et al. 1998). To address the need for large numbers of $\beta$-cells, we have been developing techniques for maintaining and expanding primary human pancreatic islet cells, derived from $\beta$-cell-enriched cultures, in vitro.
We have previously shown that isolated populations of primary adult islet cells consisting of greater than 90\% $\beta$-cells can be stimulated to divide on a complex extracellular matrix in the presence of hepatocyte growth factor/ scatter factor (HGF/SF) (Beattie et al. 1997, 1999). However, the initially strong mitogenic response ends with growth arrest after 10-15 cell divisions (Beattie et al. 1999). Several primary human cell types have been reported to 'senesce' after only a few passages in cell culture, including lens epithelial cells (Tassin et al. 1979, Reddy et al. 1988, Andley et al. 1994), arterial smooth muscle cells (Bierman 1978), kidney endothelial cells (Miller et al. 1977, Green et al. 1992) and hepatocytes (Le Guilly et al. 1973). However, these early studies chronicling life span and morphology cannot be compared mechanistically to current models of senescence, which have only been described in longer-lived cell types, such as fibroblasts. To investigate the mechanism of the growth arrest in pancreatic cells, we extended our previous observations on expanded islet cells by establishing the proliferative capacity of a series of $\beta$-cell-enriched human pancreatic islet cultures and applying many of the same studies that have been done in fibroblasts. The changes that accompanied growth arrest, which regularly occurred within 10-15 population doublings (PD), are consistent with those characteristic of cellular senescence in primary 
human diploid fibroblasts (HDFs). In contrast to the fibroblast model, the senescent phenotype was not prevented by expression of the telomerase retrotranscriptase subunit, hTERT, although telomerase activity was induced. Our findings suggest that significant ex vivo expansion of primary human pancreatic $\beta$-cells will be difficult to achieve without further manipulation of cell-cycle regulatory mechanisms.

\section{Materials and Methods}

\section{Human adult islets}

Human adult islets were generously provided by the Diabetes Research Institute, Miami, FL, USA, the Department of Surgery, University of Minnesota, MN, USA and the Islet Isolation Core Facility, St Louis, MO, USA. They were isolated with an automated method as described previously (Ricordi et al. 1988) and further purified by hand picking single islets, $50-150 \mu \mathrm{m}$ diameter, after dithizone staining (Latif et al. 1988).

\section{Cell culture}

$\beta$-Cell-enriched monolayer cultures were established from dithizone-purified adult islets by two previously described methods (Beattie et al. 1999). Briefly, islet cells were sorted by flavin adenine dinucleotide (FAD) autofluorescence or by partially dissociating islets in non-enzymatic dissociating solution (DM; Sigma Corp., St Louis, MO, USA) to separate the $\beta$-cell core from outer cell layers. FAD-sorted cells were reaggregated prior to plating as described. Cell clusters from both methods were plated in tissue culture wells coated with HTB-9 matrix (Beattie et al. 1997) and grown in RPMI medium with $11.1 \mathrm{mM}$ glucose, $10 \%$ fetal bovine serum, and $25 \mathrm{ng} / \mathrm{ml} \mathrm{HGF/SF}$.

\section{$\beta$-Galactosidase staining}

Monolayer cultures were fixed with 4\% paraformaldehyde and $0 \cdot 1 \%$ glutaraldehyde. Senescence-associated (SA) $\beta$-galactosidase enzymatic activity was localized essentially as described (Beattie et al. 1994) except that the reaction was carried out at $\mathrm{pH} 6$ (Dimri et al. 1995) with a $6 \mathrm{~h}$ incubation. In some cases 5-bromoindolyl $\beta$-Dgalactopyranoside (Bluo-Gal; Life Technologies, Grand Island, NY, USA) was used as a substrate instead of X-Gal (5-bromo-4-chloro-3-indolyl $\beta$-D-galactopyranoside).

\section{Telomere length comparisons}

Genomic DNA was isolated by proteinase K digestion and phenol-chloroform extraction. For telomere length comparisons, $3 \cdot 0 \mu \mathrm{g}$ genomic DNA were digested with Rsa1 and Hinf1 restriction enzymes and separated on a $0.6 \%$ agarose gel. The DNA was transferred to a positively charged nylon membrane by Southern blot and probed with $5^{\prime}-(\text { CCCTAA })_{5}\left[{ }^{32} \mathrm{P}\right]$. Radioactive signals were detected on X-ray film and scanned with a Hewlett Packard ScanJet 6100C (Hewlett Packard, Greeley, CO, USA). Signal densities were analyzed with Scion Image software (Scion Corp., Frederick, MD, USA). Mean telomere restriction fragment (TRF) lengths were calculated as previously described (Harley et al. 1990).

\section{Immunoblotting}

Whole-cell extracts were prepared by washing cell pellets in PBS and resuspending them in $1 \times$ CHAPS Lysis Buffer (Intergen, Purchase, NY, USA). Samples were separated on a $15 \%$ polyacrylamide gel, transferred in a Mini-PROTEAN II Trans-Blot apparatus (Bio-Rad, Hercules, CA, USA) to Hybond-P PVDF membrane (Amersham, Arlington Heights, IL, USA) and probed with anti-human p16 ${ }^{\mathrm{INK} 4}$ monoclonal antibody G175405 (Pharmingen, San Diego, CA, USA). The blot was then incubated with horseradish peroxidase-conjugated goat anti-mouse secondary antibody (Biosource International, Camarillo, CA, USA) followed by enhanced chemiluminescence detection (Amersham) as directed by the manufacturer. The results were visualized on X-ray film.

\section{Immunohistochemistry}

Monolayers were grown on glass slides, fixed in $4 \%$ paraformaldehyde, and stained as previously described (Beattie et al. 1999) using a triple combination of the primary antibodies: rabbit anti-COOH-terminal PDX-1 (a kind gift from Dr Joel Habener, Massachusetts General Hospital, Boston, MA, USA), goat anti-human hepatocyte nuclear factor 4 alpha (HNF4 $\alpha$ ) (Santa Cruz Biotechnology, Santa Cruz, CA, USA), and mouse anti-human KL1 (pan-cytokeratin; Immunotech, Westbrooke, ME, USA). Slides were analyzed using a confocal microscope (Bio-Rad MRC 1024) by scanning at confocal planes of $0 \cdot 3 \mu \mathrm{m}$ thickness. Fluorescent images were collected, and color composite images were generated using Adobe Photoshop 4 on an iMAC.

\section{Results}

Human pancreatic islet cells have a short proliferative life span in culture

To extend our previous observations on growth arrest of islet cells, we established a larger series of in vitro cultures from human pancreatic islets that were $\beta$-cell enriched based on FAD (Van de Winkle et al. 1982, Beattie et al. 1999) or partial dissociation with EDTA (Beattie et al. 1999). Cell strains BC1-BC18 were established from 18 different human pancreases harvested from donors of 
Table 1 Characteristics of maximally expanded cell strains

\begin{tabular}{|c|c|c|c|}
\hline \multirow[b]{2}{*}{ Cell strain } & \multicolumn{2}{|c|}{ Donor age, sex } & \multirow[t]{2}{*}{ Terminal passage (PD) } \\
\hline & & & \\
\hline BC1 & 16 & M & $5(\geq 15)$ \\
\hline BC5 & 42 & $\mathrm{~F}$ & $3(\geq 9)$ \\
\hline BC6 & 42 & $M$ & $3(\geq 9)$ \\
\hline $\mathrm{BC} 11$ & 18 & M & $4(\geq 12)$ \\
\hline $\mathrm{BC} 17$ & 57 & $\mathrm{~F}$ & $4(\geq 12)$ \\
\hline BC18 & 3 & M & $4(\geq 12)$ \\
\hline
\end{tabular}

various ages ranging from 3 to 57 years. Of these, six lines were maximally expanded. In each case, cells consistently stopped dividing within 10-15 PD (three to five passages at 1:8 dilution). No consistent correlation was observed between growth capacity and donor age (Table 1).

\section{Morphological changes in growth-arrested cells}

Loss of proliferation was invariably accompanied by morphological changes (Fig. 1), including enlargement and vacuolization of the cell body and, in some cases, multinucleation. These morphological alterations are consistent with those previously described in well-characterized models of cellular senescence (Stanulis-Praeger 1987, Wheaton et al. 1996). Therefore, we tested whether other currently accepted markers of senescence were present in the growth-arrested pancreatic cells.

Growth arrest is associated with up-regulation of $S A$ $\beta$-galactosidase expression

Up-regulation of SA $\beta$-galactosidase activity has been recognized as a marker of cellular senescence (Dimri et al.
1995). This enzyme can be detected at a higher $\mathrm{pH}$ than lysosomal $\beta$-galactosidase. We have previously shown that lysosomal $\beta$-galactosidase is not highly expressed in human adult islets (Beattie et al. 1994). However, we found that activity levels of SA $\beta$-galactosidase, also very low in primary cell monolayers, increased dramatically with length of culture (Fig. 1).

\section{p16 levels in cells undergoing growth arrest}

Expression of the $\mathrm{p} 16^{\mathrm{INK} 4 \mathrm{a}}$ tumor suppressor protein increases dramatically in senescent cells (Alcorta et al. 1996), and may play a role in senescence-related growth arrest. Therefore, we compared p16 levels in unexpanded and cultured pancreatic islet cells by Western blot. Extracts prepared from fetal pancreatic islet-like cell clusters, adult pancreatic islets, and early passage $\mathrm{BC} 18$ cultures contained barely detectable levels of p16 protein (Fig. 2, lanes 3-5). In sharp contrast, p16 was highly expressed in growth-arrested BC18, BC5, BC11 (Fig. 2, lanes 6-10) and BC6 cultures (not shown). Saos2 cells and K562 cells were used as positive and negative controls respectively.

\section{Growth-arrested islet cells have short telomeres}

Cellular senescence is thought to occur as a result of telomere shortening during DNA replication. In primary HDFs, the best-studied model of senescence, telomere erosion occurs over more than 40 cell divisions (Harley et al. 1990). Since the islet cell cultures growth arrest after only 10-15 PD, we were particularly interested in examining telomere length dynamics in these cells. Primary epithelial cultures from three different islet preparations that had been maximally expanded were harvested at
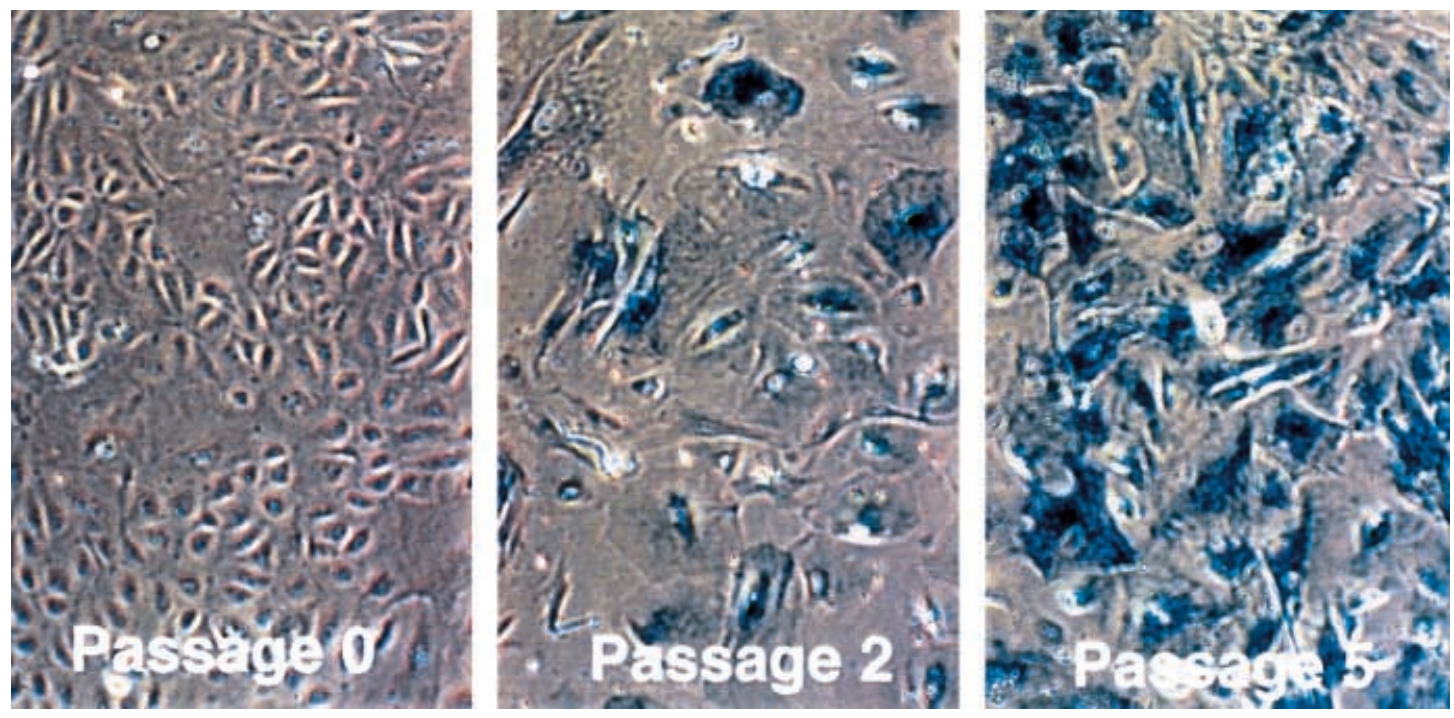

Figure 1 Phase contrast microphotograph showing localization of SA $\beta$-galactosidase activity in islet-derived monolayers at passage 0 (3PD), passage $2(9 \mathrm{PD})$, and passage $5(\geq 15 \mathrm{PD})$. Magnification: $\times 100$. 


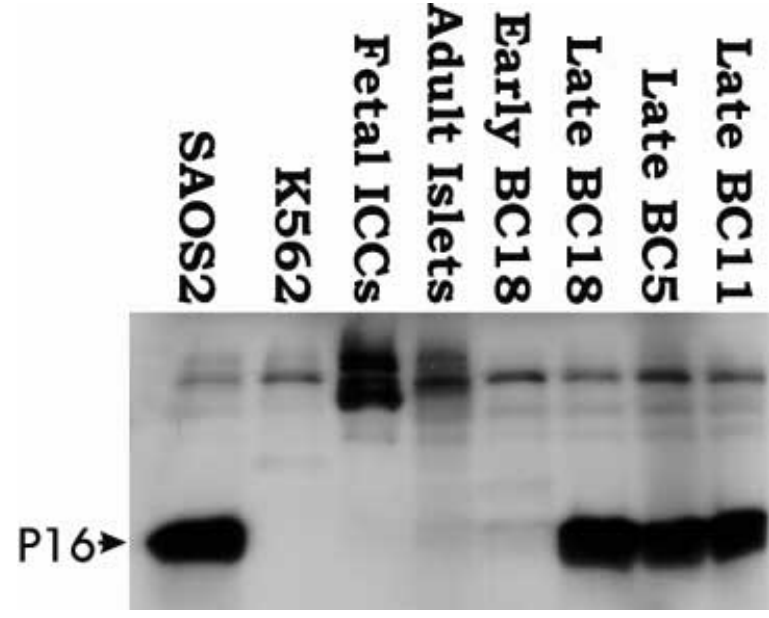

Figure 2 Western blot illustrating p16 expression levels in human pancreatic islet explants and in derived cell strains at early and late passages. Saos2 cells, which express high levels of p16 (Li et al. 1994), and K562 cells, which lack the p16 gene (Quesnel et al. 1996), served as positive and negative controls respectively.

growth arrest for genomic DNA analysis. TRF lengths were compared on a Southern blot with those of adult or fetal islets prior to expansion, telomerase-positive, transformed pancreatic cell lines (Halvorsen et al. 1999), and late passage and senescent HDFs (Fig. 3). The TRFs of expanded primary islet cells were markedly shorter than
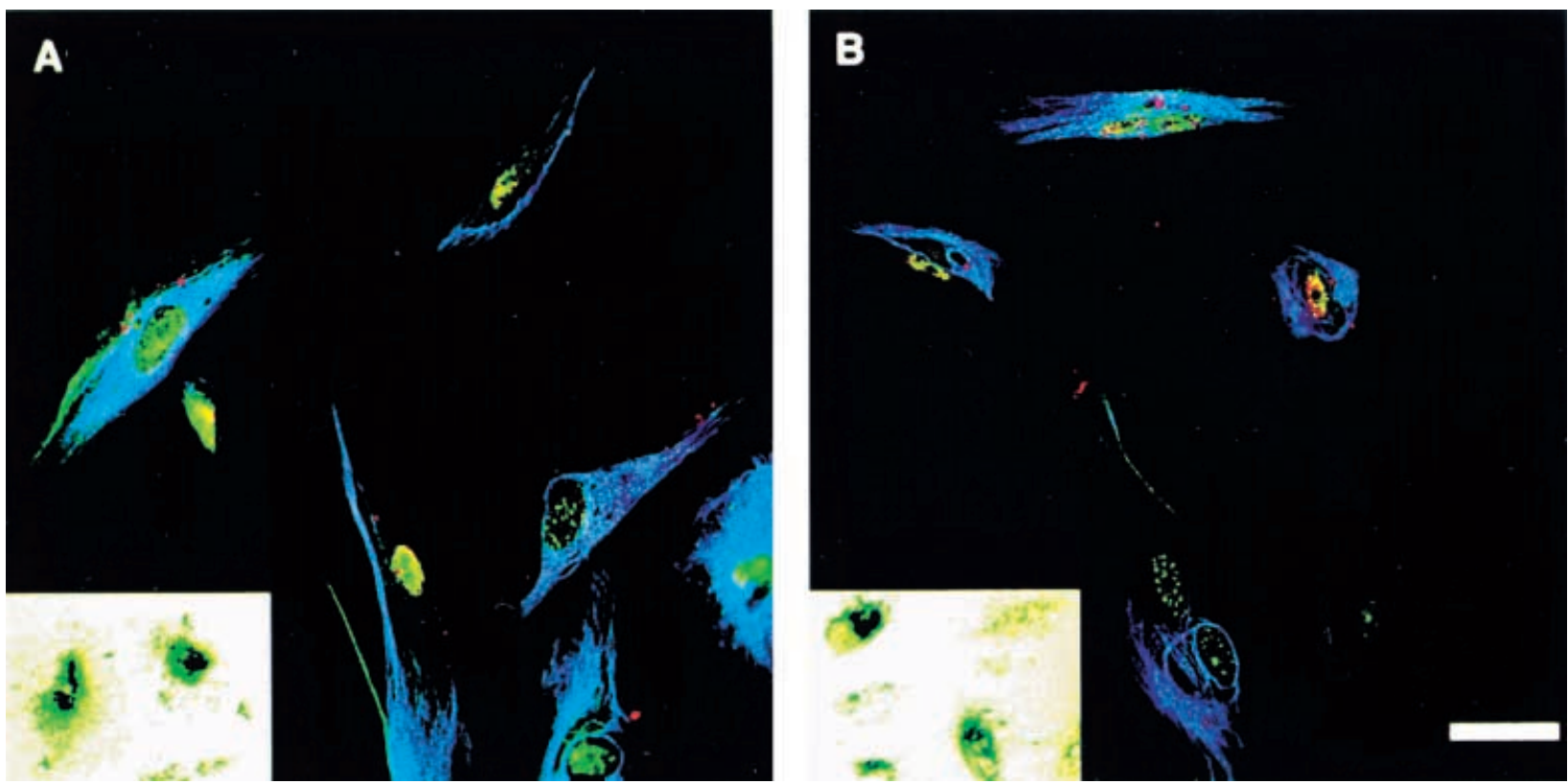

Figure 4 Confocal microscope image of monolayers of BC11 (A) and G418-selected BC11 TRT (B) at passage 4 immunostained for the epithelial marker pan-cytokeratin (blue), and the insulin transcription factors PDX-1 (green) and HNF-4 $\alpha$ (red). All cells are epithelial and all nuclei show punctate staining for PDX-1. Bar $=5 \mu \mathrm{m}$. Insets are light microphotographs of SA $\beta$-galactosidase activity in cells from the culture identical to that of the confocal image. 
those of unexpanded adult or fetal cells, or the transformed lines, but were comparable in length to TRFs of late passage or senescent HDFs. Mean TRF lengths, which include a variable length of subtelomeric sequences, decreased from $9 \mathrm{~kb}$ in adult islets to $6-6.5 \mathrm{~kb}$ in expanded cell populations. Maximum TRF lengths and signal intensity were also dramatically reduced in the expanded cells, consistent with loss of telomeric repeat sequences.

\section{Telomerase activity is not sufficient to prevent growth arrest}

Telomerase is a multisubunit riboprotein that maintains telomere length in germ cells, stem cells, and many immortal cell lines. Telomerase activity is absent in most normal somatic cells, but can be induced by exogenous expression of a species-specific retrotranscriptase subunit. The human homologue, hTERT, has been shown to immortalize primary human fibroblasts and some human epithelial cells (Bodnar et al. 1998). Therefore, we used a Moloney murine-derived retroviral vector, LTRTNLlox, to introduce hTERT into primary pancreatic islet-derived cell cultures. We have tested this vector in primary human fibroblasts and transformed human pancreatic cell lines and demonstrated that it is capable of extending the proliferative life span of these cell types (Halvorsen et al. 1999). A green fluorescent protein-expressing retrovirus, LGRNL (Halvorsen et al. 1999), was used for control infections. Both retroviral vectors impart neomycin and G418 (Geneticin, GIBCO BRL, Grand Island, NY, USA) resistance.

In separate experiments, we infected five BC lines, as well as unsorted, dispersed adult islets, with hTERTexpressing retroviruses. In every case, the cells entered a period of enlarged morphology, slowed growth and increased cell death, similar to that observed in hTERTnegative cells. Eventually, the pure cultures overtly senesced and others were overtaken by fibroblasts or other contaminants. Since we consistently observed no extension of the proliferative life span in hTERT-transduced cells, we characterized one of the telomerase-positive lines, BC11TRT, in more detail.

BC11 cells were infected with LTRTNLlox at four different multiplicities of infection (MOIs) (1, 5, 10 and 20) or LGRNL (MOI of 10) in the presence of HGF at passage 3. The retroviral infection efficiency in isletderived, dispersed monolayers (passage 1) typically exceeds $20 \%$ under these conditions (Leibowitz et al. 1999). The infected wells were split into parallel cultures grown in the presence of G418 (to confirm successful infection by LTRTNLlox) or in G418-free media (to foster optimal growth). Because the $\mathrm{BC}$ cultures sometimes retain small numbers of pancreatic fibroblasts, the islet-specific origin of the G418-selected BC11TRT cells was confirmed by confocal microscopy. Both control and LTRTNLloxinfected cells expressed endocrine markers PDX-1 (Beattie et al. 1999) and HNF-4a (Navas et al. 1999), and

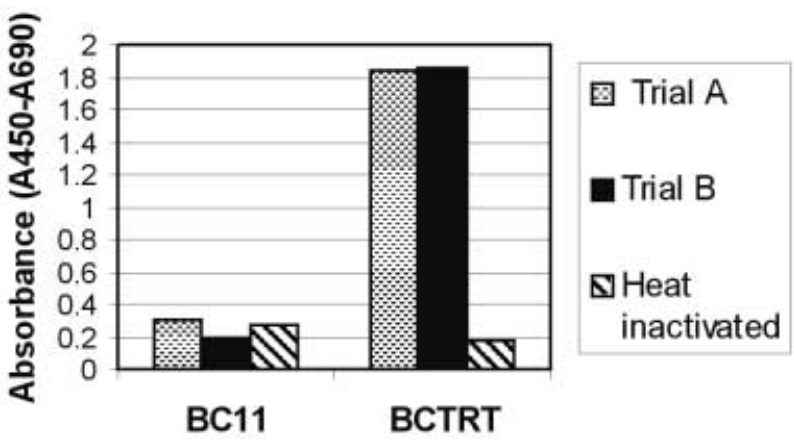

Figure 5 ELISA-based TRAP assay demonstrating acquisition of telomerase activity in BC11 cells transduced with the hTERT gene.

epithelial marker pan-cytokeratin (Beattie et al. 1999) (Fig. 4). BC11 cells continued to divide until late in passage 4. In contrast to fibroblasts and transformed pancreatic cells, both selected and unselected BC11TRT cells underwent identical morphological changes and became growth-arrested at the same time as controls. In addition, SA $\beta$-galactosidase expression was detected in G418-selected, LTR TNLlox-infected cells (Fig. 4, insets). The growth arrest was not due to failure of the vector to express hTERT because telomerase activity was present in hTERT-transgenic cells even after the cells stopped dividing, as demonstrated by telomeric repeat amplification protocol (TRAP) (Fig. 5).

\section{Discussion}

Our results demonstrate that cellular senescence is responsible for the proliferative failure that is consistently observed in primary human pancreatic islet-derived cell cultures after 10-15 PD. This finding has significant implications for the development of a cell-based therapy for insulin-dependent diabetes mellitus (IDDM) using primary pancreatic tissue. The expansion of primary $\beta$-cells has been thought to be an extremely promising technology to provide sufficient quantities of tissue for therapeutic transplantation in diabetics. Because growthstimulated cells lose many differentiated characteristics during proliferation, including insulin expression (Beattie et al. 1996), recovery of differentiated function is vital to the use of expanded primary $\beta$-cells. Unfortunately, the ability of expanded cell populations to respond to differentiating stimuli diminishes steadily as the number of PD increases (Beattie et al. 1999). It is now apparent that this may be due to the loss or alteration of differentiated function characteristic of senescent cells (Hornsby et al. 1987, Campisi 1997).

Telomere shortening has been proposed as an important trigger of cellular senescence. Our results confirm that telomere shortening also occurs in HGF/SF-stimulated, 
cultured pancreatic islet cells and that growth-arrested islet cell populations have mean TRF lengths comparable to those found in senescent fibroblast cultures. However, the kinetics of telomere shortening and the effects of telomerase activity differ between the two cell types. The mean TRFs of islet cells prior to expansion are at least $2 \cdot 5-3 \mathrm{~kb}$ higher than those of growth-arrested cells. This difference is similar to the loss in telomere length that occurs in primary adult fibroblast populations that have been cultured to senescence (Harley et al. 1990, Allsopp \& Harley 1995). However, whereas islet cell cultures senesce after 10-15 PD, the population doubling capacity of primary adult fibroblast clones ranges from 20 to more than $60 \mathrm{PD}$ (Harley et al. 1990, Allsopp et al. 1992, Cristofalo et al. 1998). This disparity cannot be accounted for by differences in cell loss during growth and passaging. Therefore, telomere erosion appears to be occurring at a much faster rate (i.e. over fewer cell divisions) in islet cells than in fibroblasts.

The demonstration that $\beta$-cell-enriched human pancreatic islet cell cultures senesce rapidly in culture suggests that it may not be possible to achieve sufficient expansion of primary human pancreatic $\beta$-cells without introducing chemical or genetic alterations that will prevent or bypass the senescence program. Based on the fibroblast model, one potentially helpful modification would be the induction of telomerase activity. Telomerase is a multisubunit riboprotein that maintains telomere length in germ cells, stem cells, and many immortal cell lines. The human homologue of the retrotranscriptase subunit, hTERT, is sufficient to reconstitute telomerase activity in many human cell types (Weinrich et al. 1997, Bodnar et al. 1998, Nakayama et al. 1998, Halvorsen et al. 1999, Yang et al. 1999) and has been shown to immortalize primary human fibroblasts without causing transformation or compromising genomic stability (Jiang et al. 1999, Vaziri et al. 1999). However, we have consistently found that transduction of the hTERT gene and induction of telomerase activity have no observable effect on the proliferative life span of pancreatic islet cell cultures. Although this result contrasts markedly with the fibroblast model, it is consistent with the demonstration of Kiyono et al. (1998) that telomerase activity is insufficient to immortalize human primary keratinocyte cultures. Kiyono's group was also able to confirm that telomere length was maintained in telomerasepositive keratinocytes, suggesting that factors other than telomere shortening may drive the senescence program in some cell types. Notably, both telomere-dependent and telomere-independent models of senescence have implicated $\mathrm{p} 16^{\mathrm{INK} 4 \mathrm{~A}}$ and possibly $\mathrm{p} 21^{\mathrm{CIP} 1 / \mathrm{WAF} 1}$. This is in accord with our previous work showing that SV40 large T antigen, which interferes with both $\mathrm{p} 16 / \mathrm{Rb}$ and p53/p21 pathways, cooperates with activated Ras to extend the growth potential of islet-derived epithelial cells (Wang et al. 1997, Halvorsen et al. 1999), and that these transformed cell lines can be immortalized by hTERT expression (Halvorsen et al. 1999). A better understanding of the pathways involved in growth and senescence in human pancreatic islet cells will facilitate the generation of future cell lines and may be critical to the development of cell-based therapies for IDDM.

\section{Acknowledgements}

We thank Dr J Rubin (National Cancer Institute, National Institutes of Health (NIH)) for his kind gift of HGF/SF. This work was supported by grants DK55065 and DK55283 from the NIH (F L), 197035 (F L) and 198225 (A H) from the Juvenile Diabetes Foundation and the Herbert O Perry fund (A H). F L is a member of the University of California San Diego Cancer Center, Center for Molecular Genetics and Whittier Institute for Diabetes.

\section{References}

Alcorta DA, Xiong Y, Phelps D, Hannon G, Beach D \& Barrett JC 1996 Involvement of the cyclin-dependent kinase inhibitor p16 (INK4a) in replicative senescence of normal human fibroblasts. PNAS 93 13742-13747.

Allsopp RC \& Harley CB 1995 Evidence for a critical telomere length in senescent human fibroblasts. Experimental Cell Research 219 130-136.

Allsopp RC, Vaziri H, Patterson C, Goldstein S, Younglai EV, Futcher AB, Greider CW \& Harley CB 1992 Telomere length predicts replicative capacity of human fibroblasts. Proceedings of the National Academy of Sciences of the USA 89 10114-10118.

Andley UP, Rhim JS, Chylack LT Jr \& Fleming TP 1994 Propagation and immortalization of human lens epithelial cells in culture. Investigative Ophthalmology and Visual Science 35 3094-3102.

Beattie GM, Levine F, Mally MI, Otonkoski T, O'Brien JS, Salomon DR \& Hayek A 1994 Acid beta-galactosidase: a developmentally regulated marker of endocrine cell precursors in the human fetal pancreas. Journal of Clinical Endocrinology and Metabolism 78 $1232-1240$.

Beattie GM, Rubin JS, Mally MI, Otonkoski T \& Hayek A 1996 Regulation of proliferation and differentiation of human fetal pancreatic islet cells by extracellular matrix, hepatocyte growth factor, and cell-cell contact. Diabetes 45 1223-1228.

Beattie GM, Cirulli V, Lopez AD \& Hayek A 1997 Ex vivo expansion of human pancreatic endocrine cells. Journal of Clinical Endocrinology and Metabolism 82 1852-1856.

Beattie GM, Itkin-Ansari P, Cirulli V, Leibowitz G, Lopez AD, Bossie S, Mally MI, Levine F \& Hayek A 1999 Sustained proliferation of PDX-1+ cells derived from human islets. Diabetes 48 1013-1019.

Bierman EL 1978 The effect of donor age on the in vitro life span of cultured human arterial smooth-muscle cells. In Vitro 14 951-955.

Bodnar AG, Ouellette M, Frolkis M, Holt SE, Chiu CP, Morin GB, Harley CB, Shay JW, Lichtsteiner S \& Wright WE 1998 Extension of life-span by introduction of telomerase into normal human cells (see comments). Science 279 349-352.

Campisi J 1997 The biology of replicative senescence. European Journal of Cancer 33 703-709.

Cristofalo VJ, Allen RG, Pignolo RJ, Martin BG \& Beck JC 1998 Relationship between donor age and the replicative lifespan of human cells in culture: a reevaluation. PNAS $9510614-10619$.

Davalli AM, Scaglia L, Zangen DH, Hollister J, Bonner-Weir S \& Weir GC 1996 Vulnerability of islets in the immediate posttransplantation period. Dynamic changes in structure and function. Diabetes 45 1161-1167. 
Dimri GP, Lee X, Basile G, Acosta M, Scott G, Roskelley C, Medrano EE, Linskens M, Rubelj I, Pereira-Smith O, Peacocke M \& Campisi J 1995 A biomarker that identifies senescent human cells in culture and in aging skin in vivo. PNAS 92 9363-9367.

Green DF, Hwang KH, Ryan US \& Bourgoignie JJ 1992 Culture of endothelial cells from baboon and human glomeruli. Kidney International 41 1506-1516.

Halvorsen TL, Leibowitz G \& Levine F 1999 Telomerase activity is sufficient to allow transformed cells to escape from crisis. Molecular and Cellular Biology 19 1864-1870.

Harley CB, Futcher AB \& Greider CW 1990 Telomeres shorten during ageing of human fibroblasts. Nature 345 458-460.

Hornsby PJ, Hancock JP, Vo TP, Nason LM, Ryan RF \& McAllister JM 1987 Loss of expression of a differentiated function gene, steroid 17 alpha-hydroxylase, as adrenocortical cells senescence in culture. PNAS 84 1580-1584.

Jiang XR, Jimenez G, Chang E, Frolkis M, Kusler B, Sage M, Beeche M, Bodnar AG, Wahl GM, Tlsty TD \& Chiu CP 1999 Telomerase expression in human somatic cells does not induce changes associated with a transformed phenotype. Nature Genetics 21 $111-114$.

Keymeulen B, Ling Z, Gorus FK, Delvaux G, Bouwens L, Grupping A, Hendrieckx C, Pipeleers-Marichal M, Van Schravendijk C, Salmela K \& Pipeleers DG 1998 Implantation of standardized beta-cell grafts in a liver segment of IDDM patients: graft and recipients characteristics in two cases of insulin-independence under maintenance immunosuppression for prior kidney graft. Diabetologia 41 452-459.

Kiyono T, Foster SA, Koop JI, McDougall JK, Galloway DA \& Klingelhutz AJ 1998 Both Rb/p16 INK4a inactivation and telomerase activity are required to immortalize human epithelial cells (see comments). Nature 396 84-88.

Latif ZA, Noel J \& Alejandro R 1988 A simple method of staining fresh and cultured islets. Transplantation 45 827-830.

Le Guilly Y, Simon M, Lenoir P \& Bourel M 1973 Long-term culture of human adult liver cells: morphological changes related to in vitro senescence and effect of donor's age on growth potential. Gerontologia 19 303-313.

Leibowitz G, Beattie GM, Kafri T, Cirulli V, Lopez AD, Hayek A \& Levine F 1999 Gene transfer to human pancreatic endocrine cells using viral vectors. Diabetes 48 745-753.

Li Y, Nichols MA, Shay JW \& Xiong Y 1994 Transcriptional repression of the D-type cyclin-dependent kinase inhibitor $\mathrm{p} 16$ by the retinoblastoma susceptibility gene product $\mathrm{pRb}$. Cancer Research 54 6078-6082.

Miller RC, Nichols WW, Pottash J \& Aronson MM 1977 in vitro aging. Cytogenetic comparison of diploid human fibroblast and epithelioid cell lines. Experimental Cell Research 110 63-73.

Nakayama J, Tahara H, Tahara E, Saito M, Ito K, Nakamura H, Nakanishi T, Ide T \& Ishikawa F 1998 Telomerase activation by
hTRT in human normal fibroblasts and hepatocellular carcinomas. Nature Genetics 18 65-68.

Navas MA, Munoz-Elias EJ, Kim J, Shih D \& Stoffel M 1999 Functional characterization of the MODY1 gene mutations HNF4(R127W), HNF4(V255M), and HNF4(E276Q). Diabetes 48 1459-1465.

Quesnel B, Preudhomme C, Lepelley P, Hetuin D, Vanrumbeke M, Bauters F, Velu T \& Fenaux P 1996 Transfer of p16 inka/CDKN2 gene in leukaemic cell lines inhibits cell proliferation. British Journal of Haematology 95 291-298.

Reddy VN, Lin LR, Arita T, Zigler JS Jr \& Huang QL 1988 Crystallins and their synthesis in human lens epithelial cells in tissue culture. Experimental Eye Research 47 465-478.

Ricordi C, Lacy PE, Finke EH, Olack BJ \& Scharp DW 1988 Automated method for isolation of human pancreatic islets. Diabetes 37 413-420.

Stanulis-Praeger BM 1987 Cellular senescence revisited: a review. Mechanisms of Ageing and Development 38 1-48.

Tassin J, Malaise E \& Courtois Y 1979 Human lens cells have an in vitro proliferative capacity inversely proportional to the donor age. Experimental Cell Research 123 388-392.

Van de Winkle M, Maes E \& Pipeleers D 1982 Islet cell analysis and purification by light scatter and autofluorescence. Biochemical and Biophysical Research Communications 107 525-532.

Vaziri H, Squire JA, Pandita TK, Bradley G, Kuba RM, Zhang H, Gulyas S, Hill RP, Nolan GP \& Benchimol S 1999 Analysis of genomic integrity and p53-dependent G1 checkpoint in telomerase-induced extended-life-span human fibroblasts. Molecular and Cellular Biology 19 2373-2379.

Wang S, Beattie GM, Mally MI, Cirulli V, Itkin-Ansari P, Lopez AD, Hayek A \& Levine F 1997 Isolation and characterization of a cell line from the epithelial cells of the human fetal pancreas. Cell Transplantation 6 59-67.

Weinrich SL, Pruzan R, Ma L, Ouellette M, Tesmer VM, Holt SE, Bodnar AG, Lichtsteiner S, Kim NW, Trager JB, Taylor RD, Carlos R, Andrews WH, Wright WE, Shay JW, Harley CB \& Morin GB 1997 Reconstitution of human telomerase with the template RNA component hTR and the catalytic protein subunit hTRT. Nature Genetics 17 498-502.

Wheaton K, Atadja P \& Riabowol K 1996 Regulation of transcription factor activity during cellular aging. Biochemistry and Cell Biology $\mathbf{7 4}$ 523-534.

Yang J, Chang E, Cherry AM, Bangs CD, Oei Y, Bodnar A, Bronstein A, Chiu CP \& Herron GS 1999 Human endothelial cell life extension by telomerase expression. Journal of Biological Chemistry 274 26141-26148.

Received 16 February 2000

Accepted 22 February 2000 